\title{
Nasal Carriage of Staphylococcus aureus by medical students: assessment of antibiotic susceptibility and risk factors
}

\section{Tıp öğrencillerinde Nasal Staphylococcus aureus taşıyıcılığı: Antibiyotik duyarlılığı ve risk faktörlerinin değerlendirilmesi}

Fikriye Milletli Sezgin ${ }^{*}$, Sevgi Sarıhan², Havva Nur Türkoğlu², Melihcan Yağmur², Gülgüşa Bucak², Nida Şevval Büyüktatar², Semih Mert Şener², Sıla Nur Şehnaz², Naime Meriç Konar, Mustafa Kasım Karahocagil $^{4}$

${ }^{1}$ Department of Medical Microbiology, Ahi Evran University School of Medicine, Kirsehir, Turkey

${ }^{2}$ Student of Ahi Evran University School of Medicine, Kirsehir, Turkey

3Department of Biostatistics and Medical Informatics, Ahi Evran University School of Medicine, Kirsehir. Turkey

${ }^{4}$ Department of Infectious Diseases and Clinical Microbiology, Ahi Evran University School of Medicine, Kirsehir, Turkey

Corresponding author: Fikriye Milletli Sezgin, MD, Department of Medical Microbiology, Ahi Evran University School of Medicine, Kirsehir,

Turkey

E-mail: fikriye.sezgin @ahievran.edu.tr

Received/Accepted: November 12, 2019 / August 18, 2020

Conflict of interest: There is not a conflict of interest.

\section{SUMMARY}

Objective: Staphylococcus aureus (S. aureus) is the leading vector for both hospital-sourced and population-sourced infections globally and nasal carriage may be responsible for these serious infections. The aim of this study was to assess the nasal $S$. aureus carriage rates, antibiotic susceptibility and risk factors among preclinical period medical students.

Method: A total of 183 preclinical period students from Ahi Evran University Faculty of Medicine voluntarily participated in our study. They were requested to complete a survey form containing questions about demographic information, hygiene habits and medical history and possible risk factors were recorded. S. aureus isolates proliferating from nasal swab culture samples were studied with antibiotic susceptibility tests.

Results: Of the total of 183 students, 39 (21.4\%) had S. aureus proliferation identified from nasal swab samples. None of these isolates were methicillinresistant S. aureus (MRSA). Antibiotic susceptibility tests found highest resistance against penicillin (85\%). There were negative correlations between nasal spray use and allergy history with nasal S. aureus carriage. Conclusions: Medical students may each be mobile sources of bacteria in hospitals, especially as MRSA carriers. According to our results, it is necessary to note the importance of training and standard infection control precautions to prevent the increase in MRSA carriage rates in the clinical period as none of our preclinical period students carried MRSA. Advanced studies are important to monitor carriage rates.

Keywords: Staphylococcus aureus, nasal carriage, medical students.

(D) Fikriye Milletli Sezgin
(D) Sevgi Sarıhan
(i) Havva Nur Türkoğlu
(i) Melihcan Yağmur
(i) Gülgüşa Bucak
(I) Nida Şevval Büyüktatar
(D) Semih Mert Şener
(D) Sıla Nur Şehnaz
(D) Naime Meriç Konar
(D) Mustafa Kasım Karahocagil

ORCID IDs of the authors: F.M.S. 0000-0002-8317-2312 S.S. $0000-0003-1614-5813$ H.N.T. 0000-0003-1443-6094 M.Y. 0001-6425-3523 G.B. $0000-0001-5521-5349$ N.Ş.B. 0000-0003-1073-633X S.M.Ş. 0000-0002-9385-6777 S.N.Ș. 0000-0002-2719-9342 N.M.K. 0000-0002-6593-7617 M.K.K. 0000-0002-5171-7306 
Amaç: Staphylococcus aureus (S. aureus), dünya çapında hem hastane kaynaklı hem de toplum kaynaklı enfeksiyonların önde gelen etkenlerinden olmakla birlikte burun taşıyıcıllı̆ı bu ciddi enfeksiyonların sorumlusu olabilir. Bu çalışmanın amacı, preklinik dönem tıp öğrencilerinde nasal $S$. aureus taşıma oranını, antibiyotik duyarlılı̆̆ı ve risk faktörlerini değerlendirmektir.

Yöntem: Ahi Evran Üniversitesi Tip fakültesi öğrencilerinden 183 preklinik dönemde olan öğrenci gönüllü olarak çalışmamıza katılmıştır. Demografik bilgilerin, hijyen alışkanlıklarının ve tıbbi öykünün sorgulandığı anket doldurmaları istenmiş̧tir ve olası risk faktörleri kaydedilmiştir. Burun sürüntü kültür örneklerinde üreyen $S$. aureus izolatlarına antibiyotik duyarlılık testi çalışılmıştır.

Bulgular: Toplam 183 öğrencinin burun sürüntü örneğinin 39'unda (\%21,4'ünde) S. aureus üremesi saptanmıştır. Bu izolatların hiçbiri metisilin dirençli S. aureus (MRSA) değildi. Antibiyotik duyarlılık testinde en yükssek direnç penisiline (\%85) karşı tespit edilmiş̧ir. Nasal sprey kullanımı ve alerji öyküsü ile nasal S. aureus taşıyıcılığı arasında negatif korelasyon saptanmıştır.

Sonuç: Tip öğrencileri özellikle MRSA taşıyıcısı olarak hastanelerde hareketli birer bakteri kaynağı olabilirler. Sonuçlarımıza göre MRSA taşıyan preklinik dönem öğrencimiz olmamasından dolayı kliniğe geçildiği dönemde MRSA taşıyıcılık oranlarının artmaması için eğitimin ve standart enfeksiyon kontrol önlemlerinin önemine dikkat çekmek gerekmektedir. İleri çalışmalarla taşyıcilık oranlarının takibi önemlidir.

Anahtar sözcükler: Staphylococcus aureus, nasal taşı1ııılık, tıp öğrencileri

\section{INTRODUCTION}

Staphylococcus aureus (S. aureus) is encountered as a pathogenic bacteria in many significant infections including skin infections like scalded skin syndrome, cellulitis, folliculitis, and abscess, pneumonia, sepsis, meningitis, osteomyelitis, surgical area infections and toxic shock syndrome. ${ }^{1}$ The main colonization area for $S$. aureus is the nose, but it may be isolated from other regions of the body. Nasal colonization especially forms a risk for many hospital- and communityacquired $S$. aureus infections. ${ }^{2}$ In recent years, increased resistance rates to antibiotics among $S$. aureus isolates have been encountered. Methicillin-resistant $S$. aureus (MRSA) especially and reduced susceptibility rates to vancomycin cause problems with treatment. ${ }^{3,4}$ Previously MRSA isolates were mostly isolated in hospitalacquired infections, but recently communityacquired MRSA isolates have been determined., As a result, studies to identify nasal $S$. aureus carriage which may cause these infections and may spread within community are important.

While medical students in the first three-year preclinical period reflect community, when they enter clinics they act as mobile elements carrying bacteria between patients. It is known that nasal colonization may increase among health workers due to MRSA found in the hospital environment. ${ }^{7}$ In Turkey in spite of increasing presence of $S$. aureus in hospital environments, there are few studies about potential risk factors for occurrence or colonization of $S$. aureus among medical students. This study was performed to assess the nasal $S$. aureus carriage rates, antimicrobial susceptibility profiles and related risk factors among medical students before exposure to clinical internships and additionally to attract attention to the topic among students before they work in clinics.

\section{MATERIAL AND METHODS}

Study design

Our study was performed with a Medical Microbiology student research group from Ahi Evran University Faculty of Medicine from February 2019 to March 2019. Of the total of 218 students in Ahi Evran University Faculty of Medicine, 183 participated. Students accepting participation provided an informed consent form and were requested to complete a written survey about demographic information and medical history. Variables included on the survey were age, gender, dormitory residence, pet ownership, previous infections, allergies other noninfectious pathologies, smoking habits, hygiene habits, antibiotic use in the previous 3 months and surgery or hospital stay in the previous 6 months. Our study received permission from Ahi Evran University Faculty of Medicine Clinical Research Ethics Committee (Decision No: 2019-01/03).

\section{Exclusion Criteria}

Participants receiving any antistaphylococcal antibiotic within the previous 2 weeks, and students with active upper respiratory tract infection during the study were excluded from the study.

\section{Collection of Samples and Bacteriologic Identification}

Nasal swab samples were taken by inserting a sterile swab $2 \mathrm{~cm}$ into the anterior region of the 
nose and slowly turning it 3-4 times. Culture samples in Stuart's transport medium (Or-bak, Turkey) at room temperature reached the laboratory within 24 hours. Samples were seeded on mannitol salt agar and incubated at $37^{\circ} \mathrm{C}$ for 24 48 hours. Positive cultures were investigated for colony morphology, gram staining and other conventional tests. Yellow colonies on mannitol salt agar were passaged for 5\% sheep's blood agar. Bacteria positive for beta hemolytic gold color pigment, gram positive cocci morphology, catalase and coagulase tests were identified as $S$. aureus.

\section{Antibiotic Susceptibility Tests}

The antibiotic susceptibility tests for $S$. aureus isolates were studied in line with recommendations of the European Committee on Antimicrobial Susceptibility Testing (EUCAST) using Mueller Hinton agar medium with the Kirby-Bauer disc diffusion method. ${ }^{8}$ Methicillin-resistant cefoxitin (30 $\mu \mathrm{g})$ discs were screened. Additionally, susceptibility tests were performed using penicillin, erythromycin, clindamycin, tetracycline, linezolid, trimethoprimsulfamethoxazole, rifampicin, gentamicin, ciprofloxacin and fucidic acid discs (Bioanalyse ${ }^{\circledR}$, Turkey). Vancomycin susceptibility was studied with E-test (bioMérieux ${ }^{\circledR}$, France) using the gradient diffusion method. For identification of inducible clindamycin resistance, erythromycin and clindamycin discs were placed as $15 \mathrm{~mm}$ distance on an MHA plate. Situations where the inhibition zone around the clindamycin disk had a straight line at the edge closest to the erythromycin disc (D-shape) were accepted as positive for inducible clindamycin resistance. In our study, (MSSA) S. aureus ATCC 29213 and (MRSA) ATCC 33591 strains were used as quality control strains.

\section{Statistical Analysis}

Descriptive statistics are given as frequency and percentage for categoric variables and as median, minimum and maximum values for numeric variables. Group comparisons used the chi-square test and the Mann-Whitney U test. To be able to determine factors affecting $S$. aureus carriage, univariate and multivariate logistic regression analysis was used. According to univariate group comparison results, $\mathrm{p}$ values smaller than 0.20 $(p<0.20)$ were included in the multivariate logistic regression model. For selection of regression analysis variables, the Backward Wald method was used. Odd's ratio and 95\% confidence intervals for Odd's ratio are given. To calculate the risk of $S$. aureus carriage among study participants, a mathematical model was created with the aid of multivariate logistic regression with ROC curve analysis applied to determine the differentiative power of the model. All statistical analyses accepted $\mathrm{p}<0.05$ as statistical significance. All analyses were performed with SPSS 22.0 (IBM Corp. Released 2013. IBM SPSS Statistics for Windows, Version 22.0. Armonk, NY: IBM Corp.).

\section{RESULTS}

A total of 183 medical faculty students participated in our research; all were in the preclinical periods with 90, 54 and 39 students voluntarily participating from period I, II and III, respectively. Of the students participating $39.3 \%$ were male and $60.7 \%$ were female with mean age $19.857 \pm 1.266$ years. The mean age for female students was $19.748 \pm 1.099$, while the mean age for male students was $20.028 \pm 1.483$ years. Of the 183 students, $39(21.4 \%)$ were identified to have $S$. aureus proliferation. S. aureus was isolated from nasal swab samples from $18(20 \%)$ period I students, $15(27 \%)$ period II students and $6(15 \%)$ period III students. All of the proliferating bacteria were methicillin-susceptible $S$. aureus (MSSA). The highest resistance was $85 \%$ against penicillin. The resistance rates to other antibiotics are given in the table (Table 1). According to the survey results, $80 \%$ of students did not smoke, $57.3 \%$ lived in dormitories, $80 \%$ did not have a family member working in a hospital, 95\% regularly washed their hands, $74 \%$ regularly washed their nasal cavities, $31.7 \%$ had frequent nose touching habits and $80 \%$ regularly washed their hands after touching their nose. There were no significant correlations found between variables like age, gender, period, smoking, antibiotic use, etc. with $S$. aureus carriage $(\mathrm{p}>0.05)$. 
Table 1: Antibiotic resistance rates in S. aureus isolates

\begin{tabular}{|l|l|}
\hline Antibiotics & Resistance $(\%) \mathbf{n = 3 9}$ \\
\hline Penicillin & $33(85)$ \\
\hline Methicillin & - \\
\hline Fusidic Acid & $5(13)$ \\
\hline Erythromycin & $9(23)$ \\
\hline Clindamycin & $4(10)$ \\
\hline Tetracycline & $5(13)$ \\
\hline Linezolid & - \\
\hline Rifampicin & - \\
\hline Trimethoprim-sulfamethoxazole & - \\
\hline Gentamicin & $20(51)$ \\
\hline Ciprofloxacin & $1(2.5)$ \\
\hline Vancomycin & - \\
\hline Inducible Clindamycin resistance & \\
\hline
\end{tabular}

There were correlations found between nasal spray use and allergy history with $S$. aureus carriage $(\mathrm{p}<0.05)$. Of the 39 students with bacterial proliferation, $6(15.4 \%)$ had allergy history while of the 143 students without bacterial proliferation,
$48(33.6 \%)$ had allergy history $(\mathrm{p}<0.05)$. Of the 39 students with bacterial proliferation, $10(25.6 \%)$ did not use nasal spray while of the 143 students without bacterial proliferation, $65(45.5 \%)$ did not use nasal spray $(\mathrm{p}<0.05)$ (Table 2$)$.

Table 2: Group comparisons

\begin{tabular}{|c|c|c|c|}
\hline \multirow[t]{2}{*}{ Variable } & \multicolumn{2}{|c|}{ Proliferation } & \multirow[t]{2}{*}{ p-value } \\
\hline & Absent & Present & \\
\hline \multicolumn{4}{|l|}{ Gender } \\
\hline Male & $51(35.7)$ & $20(51.3)$ & \multirow[t]{2}{*}{0.96} \\
\hline Female & $92(64.3)$ & $19(48.7)$ & \\
\hline \multicolumn{4}{|l|}{ Period } \\
\hline I & $69(48.3)$ & $18(46.2)$ & \multirow[t]{3}{*}{0.401} \\
\hline II & $41(28.7)$ & $15(38.5)$ & \\
\hline III & $33(23.1)$ & $6(15.4)$ & \\
\hline \multicolumn{4}{|l|}{ Smoking } \\
\hline Yes & $22(15.4)$ & $4(10.3)$ & \multirow[t]{3}{*}{0.675} \\
\hline No & $112(78.3)$ & $33(84.6)$ & \\
\hline Used to-quit & $9(6.3)$ & $2(5.1)$ & \\
\hline Do you live in a dormitory? & & & \\
\hline
\end{tabular}




\begin{tabular}{|c|c|c|c|}
\hline Yes & $82(57.3)$ & $23(59)$ & \multirow[t]{2}{*}{0.999} \\
\hline No & $61(42.7)$ & $16(41)$ & \\
\hline \multicolumn{4}{|l|}{ Do you have pets? } \\
\hline Yes & $20(14)$ & $3(7.7)$ & \multirow[t]{2}{*}{0.417} \\
\hline No & $123(86)$ & $36(92.3)$ & \\
\hline \multicolumn{4}{|c|}{ Do you have chronic disease? } \\
\hline Yes & $13(9.1)$ & $1(2.6)$ & \multirow[t]{2}{*}{0.308} \\
\hline No & $130(90.9)$ & $38(97.4)$ & \\
\hline \multicolumn{4}{|c|}{ Do you have allergies? } \\
\hline Yes & 48 (33.6) & $6(15.4)$ & \multirow[t]{2}{*}{0.03} \\
\hline No & $95(66.4)$ & $33(84.6)$ & \\
\hline \multicolumn{4}{|c|}{$\begin{array}{l}\text { Do any of your family members work in } \\
\text { hospitals? }\end{array}$} \\
\hline Yes & $112(78.9)$ & $33(86.8)$ & \multirow[t]{2}{*}{0.358} \\
\hline No & $30(21.1)$ & $5(13.2)$ & \\
\hline \multicolumn{4}{|c|}{ Hand-washing frequency } \\
\hline Regular & $136(95.1)$ & $38(97.4)$ & \multirow[t]{2}{*}{0.999} \\
\hline Irregular & $7(4.9)$ & $1(2.6)$ & \\
\hline \multicolumn{4}{|c|}{ Nasal cavity washing } \\
\hline Irregular-rare & $39(27.3)$ & $7(17.9)$ & \multirow[t]{2}{*}{0.3} \\
\hline Regular-frequent & $104(72.7)$ & $32(82.1)$ & \\
\hline \multicolumn{4}{|l|}{ Nasal touching } \\
\hline Rare & $101(70.6)$ & $23(59)$ & \multirow[t]{2}{*}{0.179} \\
\hline Frequent & $42(29.4)$ & $16(41)$ & \\
\hline \multicolumn{4}{|c|}{ Hand washing after nasal touching } \\
\hline Regular & $115(81)$ & $30(76.9)$ & \multirow[t]{2}{*}{0.651} \\
\hline Irregular & $27(19)$ & $9(23.1)$ & \\
\hline \multicolumn{4}{|c|}{ Have you had a surgical operation? } \\
\hline Yes & $6(4.2)$ & $5(12.8)$ & \multirow[t]{2}{*}{0.06} \\
\hline No & $137(95.8)$ & $34(87.2)$ & \\
\hline \multicolumn{4}{|c|}{ Have you stayed in hospital? } \\
\hline Yes & $10(7)$ & $6(15.4)$ & \multirow[t]{2}{*}{0.115} \\
\hline No & $133(93)$ & $33(84.6)$ & \\
\hline \multicolumn{4}{|c|}{ Have you used antibiotics? } \\
\hline Yes & $59(41.3)$ & $18(46.2)$ & \multirow[t]{2}{*}{0.589} \\
\hline No & $84(58.7)$ & $21(53.8)$ & \\
\hline \multicolumn{4}{|c|}{ Have you used nasal spray? } \\
\hline Yes & $65(45.5)$ & $10(25.6)$ & 0.028 \\
\hline No & $78(54.5)$ & $29(74.4)$ & \\
\hline Have you used inh & & & \\
\hline Yes & $3(2.1)$ & $1(2.6)$ & 0.999 \\
\hline No & $139(97.9)$ & $38(97.4)$ & \\
\hline Have you had skin & & & \\
\hline Yes & $11(7.7)$ & $4(10.3)$ & 0.742 \\
\hline No & $132(92.3)$ & $35(89.7)$ & \\
\hline Variable & Proli & ation & $\mathrm{p}$-value \\
\hline & Absent & Present & \\
\hline
\end{tabular}




\begin{tabular}{|l|c|c|c|}
\hline & & & \\
\hline Age & $20[18-26]$ & $20[18-23]$ & 0.771 \\
\hline How many people do you share a room with? & $3[0-4]$ & $5[2-9]$ & 0.329 \\
\hline How many people in your family? & $5[2-9]$ & $5[3-7]$ & 0.625 \\
\hline
\end{tabular}

Generally according to the univariate logistic regression analysis results, students with chronic disease, with pets, with family member working in the hospital, and regular hand washing after nasal touching had lower risk of bacterial proliferation ( $>0.05$ ). Those with skin infections, who used inhaler steroids, had stayed in hospital, used antibiotics, frequently touched their noses, frequently washed their nasal cavities, regularly and frequently washed their hands, stayed in dormitories and smoked or had quit smoking had higher risk of bacterial proliferation $(p>0.05)$ (Table 3).
According to multivariate logistic regression analysis, students with allergies had $68.2 \%$ less risk of bacterial proliferation compared to students without allergies (Odd's ratio: 0.318, 95\% CI: $0.109-0.930)$. Students who used nasal spray had $56.1 \%$ less risk of bacterial proliferation compared to students who did not use nasal spray (Odd's ratio: 0.439 , 95\% CI: 0.187-1.033). Additionally, those who had surgery were identified to have 7 times increased risk of bacterial proliferation (Odd's ratio: 7.136, 95\% CI: 1.678-30.356) (Table $4)$.

Table 3: Univariate logistic regression analysis results

\begin{tabular}{|c|c|c|}
\hline \multirow[t]{2}{*}{ Variable } & \multicolumn{2}{|l|}{ Univariate } \\
\hline & $\begin{array}{c}\text { Odds Ratio (95\% Confidence } \\
\text { interval) }\end{array}$ & p-value \\
\hline Age & $1.032(0.782-1.362)$ & 0.822 \\
\hline \multicolumn{3}{|l|}{ Gender } \\
\hline Male & 1 & - \\
\hline Female & $0.527(0.258-1.077)$ & 0.079 \\
\hline \multicolumn{3}{|l|}{ Period } \\
\hline $\mathrm{I}$ & 1 & - \\
\hline II & $1.402(0.639-3.08)$ & 0.399 \\
\hline III & $0.697(0.253-1.919)$ & 0.485 \\
\hline \multicolumn{3}{|l|}{ Smoking } \\
\hline Yes & 1 & - \\
\hline No & $1.621(0.521-5.036)$ & 0.404 \\
\hline Used to-quit & $1.222(0.189-7.9)$ & 0.833 \\
\hline \multicolumn{3}{|c|}{ Do you live in a dormitory? } \\
\hline No & 1 & - \\
\hline Yes & $1.069(0.521-2.195)$ & 0.855 \\
\hline \multicolumn{3}{|c|}{ Do you have pets? } \\
\hline No & 1 & - \\
\hline Yes & $0.513(0.144-1.823)$ & 0.302 \\
\hline \multicolumn{3}{|c|}{ Do you have chronic disease? } \\
\hline No & 1 & - \\
\hline Yes & $0.263(0.033-2.077)$ & 0.205 \\
\hline \multicolumn{3}{|c|}{ Do you have allergies? } \\
\hline No & 1 & - \\
\hline
\end{tabular}




\begin{tabular}{|c|c|c|}
\hline Yes & $0.36(0.141-0.918)$ & 0.032 \\
\hline \multicolumn{3}{|c|}{$\begin{array}{l}\text { Do any of your family members work in } \\
\text { hospitals? }\end{array}$} \\
\hline No & 1 & - \\
\hline Yes & $0.566(0.203-1.574)$ & 0.275 \\
\hline \multicolumn{3}{|c|}{ Hand-washing frequency } \\
\hline Irregular & 1 & - \\
\hline Regular & $1.956(0.233-16.392)$ & 0.536 \\
\hline \multicolumn{3}{|c|}{ Nasal cavity washing } \\
\hline Irregular-rare & 1 & - \\
\hline Regular-frequent & $1.714(0.699-4.203)$ & 0.239 \\
\hline \multicolumn{3}{|l|}{ Nasal touching } \\
\hline Rare & 1 & - \\
\hline Frequent & $1.673(0.804-3.48)$ & 0.169 \\
\hline \multicolumn{3}{|c|}{ Hand washing after nasal touching } \\
\hline Irregular & 1 & - \\
\hline Regular & $0.783(0.333-1.84)$ & 0.574 \\
\hline \multicolumn{3}{|c|}{ Have you had a surgical operation? } \\
\hline No & 1 & - \\
\hline Yes & $3.358(0.967-11.659)$ & 0.056 \\
\hline \multicolumn{3}{|c|}{ Have you stayed in hospital? } \\
\hline No & 1 & - \\
\hline Yes & $2.418(0.82-7.132)$ & 0.110 \\
\hline \multicolumn{3}{|c|}{ Have you used antibiotics? } \\
\hline No & 1 & - \\
\hline Yes & $1.22(0.599-2.488)$ & 0.584 \\
\hline \multicolumn{3}{|c|}{ Have you used nasal spray? } \\
\hline No & 1 & - \\
\hline Yes & $0.414(0.188-0.912)$ & 0.029 \\
\hline \multicolumn{3}{|c|}{ Have you used inhaler steroids? } \\
\hline No & 1 & - \\
\hline Yes & $1.219(0.123-12.058)$ & 0.865 \\
\hline \multicolumn{3}{|c|}{ Have you had skin infection? } \\
\hline No & 1 & - \\
\hline Yes & $1.371(0.412-4.569)$ & 0.607 \\
\hline
\end{tabular}


Table 4: Multivariate logistic regression analysis results

\begin{tabular}{|l|c|c|}
\hline \multirow{2}{*}{ Variable } & \multicolumn{2}{|c|}{ Multivariate } \\
\cline { 2 - 3 } & $\begin{array}{c}\text { Odds Ratio (95\% Confidence } \\
\text { interval) }\end{array}$ & p-value \\
\hline Do you have allergies? & & 0.036 \\
\hline Yes & $0.318(0.109-0.93)$ & - \\
\hline No & 1 & 0.008 \\
\hline Have you had a surgical operation? & & - \\
\hline Yes & $7.136(1.678-30.356)$ & \\
\hline No & 1 & 0.059 \\
\hline Have you used nasal spray? & $0.439(0.187-1.033)$ & - \\
\hline Yes & 1 & \\
\hline No & & \\
\hline
\end{tabular}

The model obtained with the aid of variables like having allergies or not, using nasal spray and surgical operations was found to have differentiating power for individuals with and without bacterial proliferation of AUC $=0.666$
(95\% CI: 0.578-0.754) according to ROC curve analysis $(\mathrm{p}<0.05)$. Accordingly, the differentiating power of the model was identified to be at moderate levels (Figure 1).

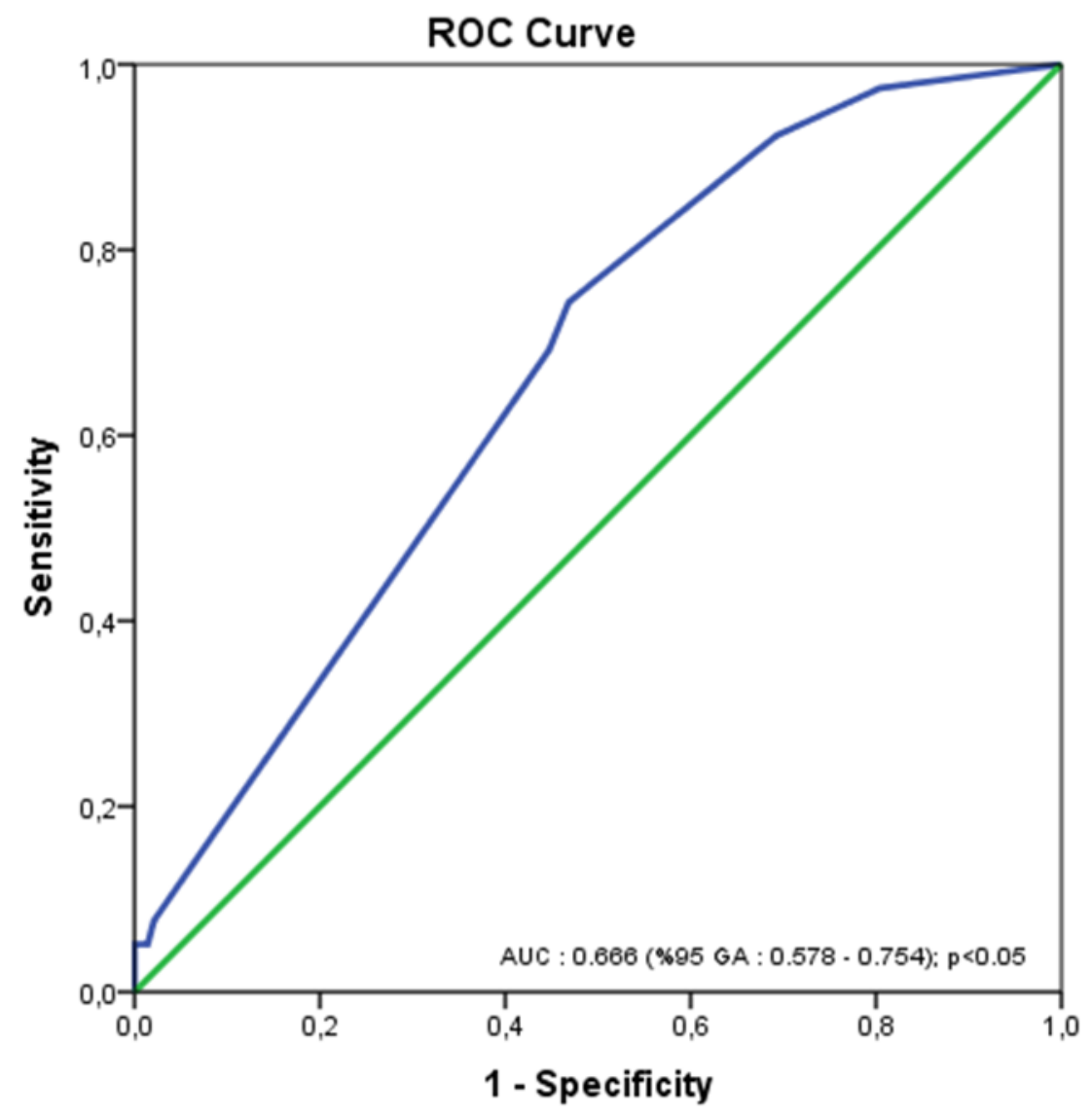

Diagonal segments are produced by ties.

Figure 1: The differentiating power of the model by ROC Curve analysis. 


\section{DISCUSSION}

There are very few publications about the nasal $S$. aureus carriage and risk factors among medical students in Turkey. Generally, health workers in hospitals (like doctors, nurses, assisting personnel) have been assessed for MRSA colonization. In our study, $21.4 \%$ of medical students were identified to have nasal $S$. aureus carriage and none had MRSA. A study by Güçlü et al. in 2006 in Turkey found $27.9 \%$ of medical students had nasal S. aureus carriage and $10 \%$ MRSA was identified. ${ }^{9}$ Another study by Türkdağ et al. in 2015 found $17.3 \%$ nasal
S. aureus carriage and reported they identified $2.9 \%$ MRSA $^{10}{ }^{10}$ International studies have found nasal S. aureus carriage and MRSA rates as $19.3 \%$ and $2.4 \%$ in Jordan in 2018, $24.7 \%$ and $0.3 \%$ in China in 2017, and $30.8 \%$ and $6.6 \%$ in Ireland, respectively. ${ }^{11-13}$ A 2013 study in Thailand found nasal $S$. aureus carriage was $20.3 \%$, while they did not identify any MRSA. ${ }^{14}$ Similarly, a 2012 study in Malaysia found $10 \%$ carriage rates; however, they stated they did not find any MRSA isolates. ${ }^{15}$ The comparison of nasal $S$. aureus carriage and MRSA rates of medical students with other studies is presented in Table 5 .

Table 5: Comparison of nasal S. aureus carriage and MRSA rates by medical students in the literature.

\begin{tabular}{|c|c|c|}
\hline Publication & Nasal S.aureus \% & MRSA \% \\
\hline $\begin{array}{l}\text { Bischoff et al., } 2004 \\
\text { USA }^{19}\end{array}$ & 29 & 2 \\
\hline $\begin{array}{l}\text { Güçlü et al., } 2006 \\
\text { Bolu, Turkey }\end{array}$ & 27.9 & 10 \\
\hline Bettin et al., 2012 Colombia ${ }^{16}$ & 25 & 1.6 \\
\hline $\begin{array}{l}\text { Gualdoni et al., 2012, } \\
\text { Austria }^{23}\end{array}$ & 25.3 & - \\
\hline $\begin{array}{l}\text { Cirkovic et al., } 2012 \\
\text { Serbia }^{24}\end{array}$ & $*$ & 0.37 \\
\hline $\begin{array}{l}\text { Chen et al., } 2012 \\
\text { Taiwan }^{20}\end{array}$ & 19.3 & 2.2 \\
\hline $\begin{array}{l}\text { Nordin et al., } 2012 \\
\text { Malaysia }\end{array}$ & 10 & - \\
\hline $\begin{array}{l}\text { Treesirichod et al., } 2013 \\
\text { Thailand }^{14}\end{array}$ & 20.3 & - \\
\hline $\begin{array}{l}\text { Türk Dă̆ı et al., } 2015 \\
\text { Konya, Turkey }\end{array}$ & 17.3 & 2.9 \\
\hline $\begin{array}{l}\text { Ansari et al., } 2016 \\
\text { Nepal }^{17}\end{array}$ & 15 & 4 \\
\hline $\begin{array}{l}\text { Okamo et al., } 2016 \\
\text { Tanzania }{ }^{25}\end{array}$ & 21 & 0.3 \\
\hline $\begin{array}{l}\text { Sarkar et al., } 2016 \\
\text { Saudi Arabia }{ }^{26}\end{array}$ & 43 & 0.4 \\
\hline $\begin{array}{l}\text { Orlin et al., } 2017 \\
\text { Israel }^{27}\end{array}$ & 33 & 12 \\
\hline $\begin{array}{l}\text { Abroo et al., } 2017 \\
\text { Iran } 18\end{array}$ & 19.6 & 13.14 \\
\hline $\begin{array}{l}\text { Budri et al., } 2017 \\
\text { Ireland }^{13}\end{array}$ & 30.8 & 6.6 \\
\hline $\begin{array}{l}\text { Chen et al., } 2017 \\
\text { China }{ }^{12}\end{array}$ & 24.7 & 0.3 \\
\hline $\begin{array}{l}\text { Al-Tamimi et al., } 2018 \\
\text { Jordan }^{11}\end{array}$ & 19.3 & 2.4 \\
\hline
\end{tabular}

*Only MRSA isolation performed.

The observations of increasing rates of antibiotic resistance among $S$. aureus isolates is a significant problem throughout the world. Medical students in the preclinical period simultaneously reflect community. Most studies investigating antibiotic susceptibility of $S$. aureus isolates from the noses of medical students found similar results to our study. For example, a study from Colombia in 2012 found $2.97 \%$ clindamycin resistance, $14.85 \%$ erythromycin resistance, inducible clindamycin resistance in one isolate and no gentamicin, trimethoprim-sulfamethoxazole, vancomycin or rifampin resistance in any isolate. ${ }^{16}$ A study from Nepal published in 2016 found high resistance to penicillin $\mathrm{G}(73.0 \%)$ among 30 isolates tested, with 2nd highest frequency for ciprofloxacin resistance (36.7\%) and stated that inducible clindamycin resistance was present in 4 isolates (13.3\%) with the D-region test. The same study emphasized that no vancomycin or teicoplanin resistant isolates were found. ${ }^{17} \mathrm{~A}$ study of medical students from Iran in 2017 identified $93.4 \%$ penicillin resistance, $27 \%$ erythromycin resistance, $19 \%$ clindamycin resistance, $12.4 \%$ trimethoprim-sulfamethoxazole 
resistance, $6.6 \%$ ciprofloxacin resistance, $2.2 \%$ gentamicin resistance and $4.4 \%$ mupirocin resistance. $^{18}$

When the socio-demographic, potential and habitual risk factors are investigated according to student responses, there was no significant correlations with nasal $S$. aureus carriage apart from negative correlations with nasal spray use and allergy history. When $S$. aureus colonizes the nose, it is a bacteria with high capacity to form biofilms. In the stage of $S$. aureus entering the nasal anterior region, we think the use of nasal spray and allergy history may mechanically prevent the infection linked to secretions and sneezing. Additionally, according to logistic regression analysis, surgical operation history increases the risk of $S$. aureus carriage by 7 times. This shows colonization linked to hospital stay. If we examine the research, Bischoff et al. in a study researching the nasal $S$. aureus carriage of medical students found significantly high rates of carriage with increasing age and with male gender. ${ }^{19}$ Research in Jordan in 2018 identified significant correlations between students with chronic disease and male gender with $S$. aureus carriage. ${ }^{11}$ In Taiwan, Chen et al. found correlations between hospital stay in the previous 1 -year, antibiotic use and male gender with $S$. aureus carriage. ${ }^{20}$ A 2017 study from China identified correlations with increased age and male gender and a significant difference with regular nasal cleaning. ${ }^{12}$ Some studies have not identified significant correlations between nasal $S$. aureus carriage and risk factors. ${ }^{14,16,17}$

We think a limitation of our study is that we only took nasal swab samples from students one time as nasal $S$. aureus carriage may be temporary or permanent. Permanent carriage may be identified by nasal $S$. aureus isolation with repeated sampling at certain intervals. There is a need to support our results with advanced studies about whether permanent carriage is present or not.

As medical students have close contact with patients in hospitals, they are important elements in the spread of pathogens to patients and the general population. Topical antibiotics may be used to resolve $S$. aureus colonization. However, some studies have emphasized that this is not a permanent solution with relapse observed and have not recommended it. ${ }^{21,22}$ Additionally, we may encounter increased resistance rates to antibiotics due to excess use. Instead, providing information to $S$. aureus carriers and providing training explaining standard precautions and especially the importance of hand hygiene to reduce bacterial spread will create awareness.

\section{CONCLUSION}

S. aureus and MRSA carriage is an important pathogen playing a role in hospital-associated infections along with population-sourced infections. The medical faculty in our university is a newly-opened faculty, with no medical students in clinic yet. Medical students in the preclinical period in our university are $S$. aureus carriers; however, it is a positive result that no MRSA carriage was found. Additionally, in order for there to be no MRSA carriers among our students when they enter the hospital, we shared our results with the students and organized awareness training. With continuous training, it is necessary to support and develop strategies to reduce transmission from hospital environment to students to keep nasal bacterial colonization low in the clinical period and to monitor rates with advanced studies.

Financial Disclosure: This work was supported by Ahi Evran University Scientific Research Project Unit with TIP.A4.19.008 project number.

\section{REFERENCES}

1.Becker K, von Eiff C. Staphylococcus, micrococcus, and other catalase-positive cocci. In: Versalovic J, Carroll KC, Jorgensen JH, Funke G, Landry ML, Warnock DW (eds). Manual of Clinical Microbiology. 10th ed. Washington DC: ASM Pres, 2011:308-31.

2.Kluytmans J, van Belkum A, Verbrugh H. Nasal carriage of Staphylococcus aureus: epidemiology, underlying mechanisms, and associated risks. Clin Microbiol Rev. 1997;10:505-20.

3.Carroll KC. Rapid diagnostics for methicillinresistant Staphylococcus aureus: current status. Mol Diagn Ther. 2008;12:15-24.

4.Appelbaum PC. Microbiology of antibiotic resistance in Staphylococcus aureus. Clin Infect Dis. 2007;45(Suppl. 3):S165-S170.

5.Naimi TS, LeDell KH, Como-Sabetti K, Borchardt SM, Boxrud DJ, Etienne J, et al. Comparison of community- and health careassociated methicillin-resistant Staphylococcus aureus infection. JAMA. 2003;290:2976-84.

6.Crawford SE, David MZ, Glikman D, King KJ, Boyle-Vavra S, Daum RS. Clinical importance of purulence in methicillin-resistant Stapylococcus aureus skin and soft tissue infections. J Am Board Fam Med. 2009;22:647-54.

7.Dulon M, Peters C, Schablon A, Nienhaus A. MRSA carriage among healthcare workers in nonoutbreak settings in Europe and the United States: a systematic review. BMC Infect Dis. 2014;14:363. 
8.The European Committee on Antimicrobial Susceptibility Testing. Breakpoint tables for interpretation of MICs and zone diameters. Version 8, 2018. http://www.eucast.org.

9.Guclu E, Yavuz T, Tokmak A, Behcet M, Karali E, Ozturk O, et al. Nasal carriage of pathogenic bacteria in medical students: effects of clinic exposure on prevalence and antibiotic susceptibility. Eur Arch Otorhinolaryngol. 2007;264:85-8.

10.Dağ1 HT, Findık D, Demirel G, Arslan U. Detection of methicillin resistance and various virulence factors in Staphylococcus aureus strains isolated from nasal carriers. Balkan med $\mathrm{j}$. 2015;32:171-5.

11.Al-Tamimi M, Himsawi N, Abu-Raideh J, Aljawaldeh $\mathrm{H}$, Mahmoud SAH, Hijjawi N, et al. Nasal colonization by methicillin-sensitive and methicillin-resistant Staphylococcus aureus among medical students. J Infect Dev Ctries. 2018;12:32635.

12.Chen BJ, Xie XY, Ni LJ, Dai XL, Lu Y, Wu $\mathrm{XQ}$, et al. Factors associated with Staphylococcus aureus nasal carriage and molecular characteristics among the general population at a Medical College Campus in Guangzhou, South China. Ann Clin Microbiol Antimicrob. 2017;16:28.

13.Budri PE, Shore AC, Coleman DC, Kinnevey PM, Humpreys H, Fitzgerald-Hughes D. Observational cross-sectional study of nasal staphylococcal species of medical students of diverse geographical origin, prior to healthcare exposure: prevalence of SCCmec, fusC, fusB and the arginine catabolite mobile element (ACME) in the absence of selective antibiotic pressure. BMJ open. 2018;8(4):e020391.

14.Treesirichod A, Hantagool S, Prommalikit O. Nasal carriage and antimicrobial susceptibility of Staphylococcus aureus among medical students at the HRH Princess Maha Chakri Sirindhorn Medical Center, Thailand: a follow-up study. J Infect Public Health. 2014;7:205-9.

15.Ahmadi S, Desa MNM. Staphylococcus aureus nasal carriers among medical students in a medical school. Med J Malaysia. 2012;67:636-8.

16.Bettin A, Causil C, Reyes N. Molecular identification and antimicrobial susceptibility of Staphylococcus aureus nasal isolates from medical students in Cartagena, Colombia. Braz J Infect Dis. 2012;16;329-34.

17.Ansari S, Gautam R, Shrestha S, Ansari SR, Subedi SN, Chhetri MR. Risk factors assessment for nasal colonization of Staphylococcus aureus and its methicillin resistant strains among preclinical medical students of Nepal. BMC Res Notes. 2016;9: 214.

18.Abroo S, Jazani NH, Sharifi Y. Methicillinresistant Staphylococcus aureus nasal carriage between healthy students of medical and nonmedical universities. Am J Infect Control. 2017;45:709-12.

19.Bischoff WE, Wallis ML, Tucker KB, Reboussin BA, Sherertz RJ. Staphylococcus aureus nasal carriage in a student community prevalence, clonal relationships, and risk factors. Infect Control Hosp Epidemiol. 2004;25:485-91.

20.Chen CS, Chen CY, Huang YC. Nasal carriage rate and molecular epidemiology of methicillinresistant Staphylococcus aureus among medical students at a Taiwanese university. Int J Infect Dis. 2012;16:e799-803.

21.Doebbeling B, Reagan D, Pfaller M, Houston AK, Hollis RJ, Wenzel RP. Long-term efficacy of intranasal mupirocin ointment. A prospective cohort study of Staphylococcus aureus carriage. Arch Intern Med. 1994;154:1505-8.

22.Kalmeijer MD, Coertjens H, van NieuwlandBollen PM, Bogaers-Hofman GA, De Baere A, Stuurman A, et al. Surgical site infections in orthopedic surgery: the effect of mupirocin nasal ointment in a double-blind, randomized, placebocontrolled study. Clin Infect Dis. 2002;35:353-8.

23.Gualdoni GA, Lingscheid $\mathrm{T}$, Tobudic $\mathrm{S}$, Burgmann H. Low nasal carriage of drug-resistant bacteria among medical students in Vienna. GMS Krankenhhyg Interdiszip. 2012;7.

24.Cirković I, Djukić S, Vuković D, Stevanović G, Svabić-Vlahović M, Stepanović S. Nasal carriage of methicillin-resistant Staphylococcus aureus among medical students of Belgrade University. Srp Arh Celok Lek. 2013;141:349-53.

25.Okamo B, Moremi N, Seni J, Mirambo MM, Kidenya BR, Mshana SE. Prevalence and antimicrobial susceptibility profiles of Staphylococcus aureus nasal carriage among preclinical and clinical medical students in a Tanzanian University. BMC Res Notes. 2016;9:47.

26.Sarkar A, Raji A, Garaween G, Soge O, ReyLadino J, Al-Kattan W, et al. Antimicrobial resistance and virulence markers in methicillin sensitive Staphylococcus aureus isolates associated with nasal colonization. Microb pathog. 2016;93:812. 
27.Orlin I, Rokney A, Onn A, Glikman D, Peretz A. Hospital clones of methicillin-resistant Staphylococcus aureus are carried by medical students even before healthcare exposure. Antimicrob Resist Infect Control. 2017;6:15. 